\title{
The Brain, The Heart and Taurine
}

\author{
ANDRÉ BARBEAU \\ Based on a recent International Symposium on Taurine held in Tucson, Arizona, \\ March 24-26, 1975.
}

\begin{abstract}
SUMMARY: This paper reviews some recent developments concerning the "non-essential" amino acid Taurine. It is shown that taurine is important in metabolic regulations within the heart, muscle and brain. Particular attention is paid to the neuropharmacology of taurine, such as its possible role in epilepsy.
\end{abstract}

RÉSUMÉ: Le présent article revoit les développements récents concernant la taurine, un acide aminé "non-essentiel". Il est conclu que la taurine est importante dans certaines régulations métaboliques au niveau du coeur, des muscles et du cerveau. Une attention particulière est portée à la neuropharmacologie de la taurine, tel son rôle possible dans l'épilepsie.

From the Clinical Research Institute of Montreal, 110 avenue des Pins ouest, Montreal H2W IR7.

Reprint requests to Dr. Barbeau at the Institute.
Taurine (2-aminoethanesulfonic acid) is a "non-essential" amino acid with a wide distribution in the budy (Jacobsen and Smith, 1968). Although nearly $75 \%$ of taurine is situated within muscles, large concentrations can also be found in the brain. The relative metabolic inertness of this amino acid led to a neglect of its physiological role within these organs. However, recent discoveries have contributed towards a renewal of interest on the part of pharmacologists and biochemists.

The concentration of taurine was first examined in urine and tissues from patients with diseases of muscle. A specific increase in taurinuria was found in most patients with muscular dystrophy (Blahd et al., 1955; Berger, 1962), in contrast to the generalized amino aciduria of myotonic dystrophy (Steinert's disease). Baskin and Dagirmanjian (1973a) recently confirmed this finding, indicating that. it most likely was an active marker of progressive muscle disease, since taurinuria decreased considerably in the amyotrophic stage. It was thus of great interest when Huxtable and Bressler (1974a, b) recently reported a marked increase in heart taurine in congestive heart failure. This finding led to a reevaluation of the metabolism and synthesis pathway of taurine which to that time had been incompletely understood. The immediate precursor was confirmed to be hypotaurine which, in turn, could originate from cysteine sulfinic acid or from cysteamine. Some of the early studies of Welty and Read (1964) on the role of taurine in the metabolic ionic balance of the heart were confirmed and extended. It would now appear that within this muscle, taurine is a modulator of membrane excitability and not a neurotransmitter (Huxtable and Bressler, 1974b).

Concentrations of taurine have been found high in the retina (Bonaventure et al., 1974), pineal gland (Guidotti et al., 1972), hypothalamus (Crabai et al., 1974) and cerebellum (Perry et al., 1971) in a variety of animal species from the rat to the human. It was thus natural that studies designed to investigate the possible role of taurine within these regions of the brain would be carried out. In the retina, Pasantes-Morales and her colleagues (1973a, b) were able to demonstrate that taurine can be specifically released by chemical as well as electrical stimulation. Moreover, they showed that the retinal concentration of taurine increased markedly when the animals were reared in darkness. This relationship between taurine and the light/darkness cycle may be carried further since, as mentioned before, this amino acid is found in high concentration within the pineal gland. Baskin and Dagirmanjian (1973b) even demonstrated that taurine can alter melatonin synthesis and/or release in the pineal gland. Taurine may also play a role in some endocrine functions. Injected intraventricularly in high doses it will produce hypophagia, a decreased water drive and a significant lowering of body temperature. There is some evidence that hypophysectomy will result in increased tissue concentrations of taurine (Awapara, 1956), while taurinuria and the urinary excretion of 17-hydroxycorticosteroids may be correlated in stress (burns, trauma) (Turner and Blum, 1964). Finally, the 
precursor hypotaurine has been shown to be in high concentration in the testes and epidydimis of many animal species and to be influenced by the testosterone content (Kochakian, 1973).

The most important recent findings concern the behavioural and neuropharmacological actions of taurine. It was shown that taurine can produce analgesia (Sugihara et al., 1936), hypothermia, slight arterial hypotension and a delay in recovery of the righting reflex with sedation (Scaragli and Pavan, 1972). A depression of habituated psychomotor activity is often coupled to loss of body balance and ataxic gait at higher doses (Baskin et al., 1974). Early studies in children with mental deficiency had demonstrated disturbances in taurine excretion, mainly in Down's syndrome (Goodman et al., 1964) and particularly when epilepsy was also present. Taurine was shown to raise the threshold of electrically or chemically induced seizures in the dog (Hayashi, 1959). In 1972, van Gelder, Sherwin and Rasmussen (1972) found modifications in the concentrations of many substances between the epileptic focus and surrounding areas of the temporal lobe in man. Of particular interest was a generalized lowering of GABA and aspartic acid levels throughout the cortex of patients with epilepsy while low levels of glutamic acid and taurine, in combination with high glycine concentrations, seemed to characterize the site of maximum seizure activity. Similar findings were soon reported in experimentally induced epileptic foci by Koyama (1972) and by Craig and Hartmann (1973), but challenged by Perry and his colleagues (1972). At this writing, the discrepancy appears to be methodological.

Van Gelder (van Gelder, 1972; van Gelder and Courtois, 1972) first reported that the administration of taurine exerted some anticonvulsant action in animals and that it modified towards normal the brain amino acid irregularities previously reported. These findings have since been confirmed by many authors in a variety of experimental epilepsy models from mice to rats, cats, dogs and even papio papio (Craig and Hartmann, 1973; Izumi et al., 1973; Tsukada et al., 1974; Izumi et al., 1974, Mutani et al., 1974a, b; Kaczmarek and Adey, 1974; Derouaux et al., 1973; Thursby, 1974; Adembri et al., 1974). There seems little doubt now that taurine possesses antiepileptic activity in experimental animals. Whether this activity is specific or not is still conjectural (Izumi et al., 1974; Adembri et al., 1974), but taurine far surpasses in epileptic inhibitory activity GABA, hypotaurine, $\boldsymbol{\beta}$-alanine and glycine (Izumi et al., 1973; Tsukada et al., 1974). The recent demonstration by McLardy (1974) that taurine blocks the zinc-rich dentato-hippocampal synapses, adds a further argument in favor of this specific action in epileptic brain. In man, only a few studies have been published, with variable results in relatively small numbers of patients (Barbeau and Donaldson, 1973 a, b; 1974; Bergamini et al., 1973, 1974; Borromei, 1975). It would appear, particularly when the blood brain barrier is damaged in the temporal lobe (Barbeau and Donaldson, 1974), that taurine can exert some anticonvulsant activity in man. Because only a minimal part of ingested taurine (less than $1 \%$ ) reaches the brain, it is evident that better methods of administration will have to be designed and tested in larger series of patients before any firm conclusion can be drawn. However, such studies have served as a powerful incentive for a number of physiological investigations of the role and mode of action of taurine within the central nervous system.

As early as 1960, Curtis and his colleagues (Curtis and Watkins, $1960,1965)$ had demonstrated that the iontophoretic injection of taurine exerts a depressor effect on most neurons. This was confirmed subsequently by Haas and Hosli (1973) and Honegger et al. (1973). What is not clear at this time is whether taurine acts as a true neurotransmitter or as a neuromodulator. Davison and Kaczmarek (Davison and Kaczmarek, 1971; Kaczmarek and Davison, 1972; Kaczmarek and Adey, 1974) have argued strongly in favor of a neurotransmitter role for this amino acid. Their arguments are based upon the demonstration: (1) that taurine can be released by electrical or chemical stimulation in vitro and in vivo (Pasantes-Morales et al., 1973 b; Kaczmarek and Adey 1974; Davison and Kaczmarek, 1971; Jasper and Koyama, 1969; Collins and Topiwala, 1974), (2) that there is a more or less specific uptake mechanism for taurine (Kaczmarek and Davison, 1972; Lähdesmäki and Oja, 1973), (3) that there is new biosynthesis of taurine after electrical stimulation, as if there were some sort of metabolic feedback control (Oja et al., 1973), and finally (4) that there is synaptosomal enrichment of taurine (De Belleroche and Bradford, 1973; Siegart and Karobath, 1974). However, some of the same arguments have been used to claim that taurine is a neuromodulator at certain brain synapses (van Gelder 1972; Honegger et al., 1973). There is also evidence that taurine uptake is not limited to neurons, but can occur within glial cells (Ehinger, 1973). Finally, it is known that taurine, through its sulfur group, can probably chelate or mobilize calcium. It has been shown to increase tissue affinity for, and retention of, calcium (Dolara et al., 1973) particularly after phospholipase -C (Huxtable and Bressler, 1973). From these studies it is our present position that taurine has a dual role to play within the brain. On most cells it is a modulator of membrane excitability (van Gelder, 1972; Barbeau and Donaldson, 1974; Huxtable and Bressler, 1973). In some specific regions, particularly in pathways responsible for the integration of specialized sensory modalities (visual, olfactory, proprioceptive), taurine may play a role as a specific neurotransmitter. In this, taurine would resemble GABA which also possesses general modulator functions and specific pathway transmitter roles. Much work remains to be done to clarify the actual role of taurine within the brain; but the studies reviewed above, and presented at a recent symposium (Huxtable and Barbeau, 1975) should point the way for further investigations. 


\section{REFERENCES}

ADEMBRI, G., BARTOLINI, A., BARTOLINI, R., GIOTTI, A., ZILLETTI, L. (1974). Anticonvulsive action of homotaurine and taurine. British Journal of Pharmacology, 52, 439-440.

AWAPARA, J. (1956). The taurine concentration of organs from fed and fasted rats. Journal of Biological Chemistry, 218, $57 !-576$.

BARBEAU, A. and DONALDSON, J (1973a). Taurine in epilepsy. The Lancet, II, 387.

BARBEAU, A. and DONALDSON, J (1973b). Zinc, taurine and epilepsy. Transactions of the American Neurological Association, $98,243-244$.

BARBEAU, A. and DONALDSON, J (1974). Zinc, taurine and epilepsy. Archives of Neurology, 30, 52-58.

BASKIN, S. I. and DAGIRMANJIAN, R. (1973a). Possible involvement of taurine in the genesis of muscular dystrophy. Nature (London), 245, 464.

BASKIN, S. I. and DAGIRMANJIAN, R. (1973b). The effect of taurine on the pigmentation of the bullfrog tadpole. Comparative Biochemistry and Physiology, 44A, 297-302.

BASKIN, S. I., HINKAMP, D. L., MARQUIS, W. J. and TILSON, H. A. (1974). Effects of taurine on psychomotor activity in the rat. Neuropharmacology, 13 591-594,

BERGAMINI, L. and MUTANI, R. (1973). Taurine: a new approach to treatment for epilepsy. Rivista sperimentale di Freniatria e Medicina Legale delle Alienzaioni Mentale, 97, 738-747.

BERGAMINI, L., MUTANI, R., DE. LSEDIME, M. and DURELLI, L. (1974). First clinical experience on the antiepileptic action of taurine. European Neurology, 11 , 261-269.

BERGER, H. (1962). Aminoaciduria in progressive muscular dystrophy. Revue Canadienne de Biologie, 21, 567-576.

BLAHD, W. H., BLOOM, A. and DRELL, W. (1955). Qualitative study of aminoaciduria in muscular dystrophy and myotonia dystrophica. Proceedings of the Society for Experimental Biology and Medicine, 90, 701-706.

BONAVENTURE, N., WIOLAND, N. and MANDEL, P. (1974). Antagonists of the putative inhibitory transmitters taurine and GABA in the retina. Brain Research, 80 , 281-289.

BORROMEI, A., SACQUEGNA, T, and COCCAGNA, G. (1975). Use of taurine in continuous partial epilepsy. Observations of a case. Phronesis, 17,401-415.

COLLINS, C. G. S. and TOPIWALA, S. H. (1974). The release of $\left({ }^{14} \mathrm{C}\right)$-taurine from slices of rat cerebral cortex and spinal cord evoked by electrical stimulation and high potassium ion concentrations. British Journal of Pharmacology, 50, 471.

CRABAI, F., SITZIA, A. and PEPEU, G.
(1974). Taurine concentration in the neurohypophysis of different animal species. Journal of Neurochemistry, 23, 1091-1092.

CRAIG, C. R. and HARTMANN, E, R. (1973). Concentration of amino acids in the brain of cobalt-epileptic rat. Epilepsia (Amst.), 14, 409-414.

CURTIS, D. R. and WATKINS, J. C. (1960). The excitation and depression of spinal neurones by structurally related amino acids. Journal of Neurochemistry, 6 , 117-141.

CURTIS, D. R. and WATKINS, J. C. (1965). The pharmacology of amino acids related to gamma-aminobutyric acid. Pharmacological Reviews, 17, 347-391.

DAVISON, A. N. and KACZMAREK, L. K. (1971). Taurine-A possible neurotransmitter. Nature, 234, 107-108.

DE BELLEROCHE, J. S, and BRADFORD, H. F. (1973). Amino acids in synaptic vesicles from mammalian cerebral cortex: A reappraisal. Journal of Neurochemistry $21,441-451$

DEROUAUX, M., PUIL, E. and NAQUET, R. (1973). Antiepileptic effect of taurine in photosensitive epilepsy. Electroencephalography and Clinical Neurophysiology, 34, 770.

DOLARA, P., AGRESTI, A., GIOTTI, A. and PASQUINI, G. (1973). Effect of taurine on calcium kinetics of guinea-pig heart. European Journal of Pharmacology, 24, 352-358.

EHINGER, B. (1973) Glial uptake of taurine in the rabbit retina. Brain Research, 60 , 512-516.

GOODMAN, H. O., KING, J. S, and THOMAS, J. J. (1964). Urinary excretion of beta-aminobutyric acid and taurine in mongolism. Nature, 204, 650-652.

GUIDOTTI, A., BADIANI, G. and PEPEU, G. (1972). Taurine distribution in cat brain. Journal of Neurochemistry, 19, 431-435.

HAAS, H. L. and HOSLI, L. (1973). The depression of brain stem neurones by taurine and its interaction with strychnine and bicuculline. Brain Research, 52, 399-402.

HAYASHI, T. (1959). The inhibitory action of a $\boldsymbol{B}$-hydroxy- $\boldsymbol{y}$-aminobutyric acid upon the seizure following stimulation of the motor cortex of the dog. Journal of Physiology (London), 145, 570-578.

HONEGGER, C. G., KREPELKA, L. M., STEINER, $M$. and VON HAHN, H. P. (1973). Kinetics and subcellular distribution of $\mathrm{S}^{\mathbf{3 5}}$ - Taurine uptake in rat cerebral cortex slices. Experientia (Basel) 29, 1235-1237.

HUXTABLE, R and BARBEAU, A. (Eds.) (1975). Taurine. Raven Press, New York. (in press).

HUXTABLE, R. and BRESSLER, R. (1973). Effect of taurine on a muscle intracellular membrane. Biochimica et Biophysica Acta. 323, 573-583.

HUXTABLE, R. and BRESSLER, R. (1974a). Taurine concentrations in congestive heart failure. Science, 184, 1187-1188.
HUXTABLE, R. and BRESSLER, R. (1974b). Elevation of taurine in human congestive heart failure. Life Sciences, 14, 1353-1359.

IZUMI, K., DONALDSON, J., MINNICH, J. L. and BARBEAU, A. (1973). Ouabaininduced seizures in rats: Suppressive effects of taurine and $\boldsymbol{y}$-aminobutyric acid. Canadian Journal of Physiology and Pharmacology, 51, 885-889.

IZUMI, K., IGISU, $H$. and FUKUDA, T. (1974). Suppression of seizures by taurinespecific or non specific? Brain Research, $76,171-173$.

JACOBSEN, J. G. and SMITH, L. L. H. (1968). Biochemistry and physiology of taurine and taurine derivatives. Physiological Reviews, 48, 424-511.

JASPER, H. H. and KOYAMA, I. (1969). Rate of release of amino acids from the cerebral cortex in the cat as affected by brain stem and thalamic stimulation. Canadian Journal of Physiology and Pharmacology, 47, 889-905.

KACZMAREK, L. K. and ADEY, W. R. (1974). Factors affecting the release of $\left({ }^{14} \mathrm{C}\right)$ taurine from cat brain: The electrical effects of taurine on normal and seizure prone cortex. Brain Research, 76, 83-94.

KACZMAREK, L. K. and DAVISON, A. N. (1972). Uptake and release of taurine from rat brain slices. Journal of Neurochemistry. 19, 2355-2362.

KOCHAKIAN, C. D. (1973), Hypotaurine: regulation of production in seminal vesicles and prostate of guinea-pig by testosterone. Nature, 241, 202-203.

KOYAMA, 1. (1972). Amino acids in the cobalt-induced epileptogenic and nonepileptogenic cat's cortex. Canadian Journal of Physiology and Pharmacology, 50, 740-752.

LÄHDESMÄKI, P. and OJA, S. S. (1973). On the mechanism of taurine transport at brain cell membranes. Journal of Neurochemistry, 20, 1411-1417.

McLARDY, T. (1974). Prolonged blockage by taurine of dentalo-hippocampus synapses in rats. International Research Communications Synopsis, 2. 1696.

MUTANI, R., BERGAMINI. L., DE. LSEDIME, M. and DURELLLI. L. (1974a). Effects of taurine in chronic experimental epilepsy. Brain Research, 79. 330-332.

MUTANI, R., BERGAMINI, L.. FARIELLO, $R$. and DELSEDIME. $M$. (1974b). Effects of taurine on cortical acute epileptic foci. Brain Research, 70, 170-173.

OJA, S. S., KARVONEN, M. L. and LÄHDESMÄKI, P. (1973). Biosynthesis of taurine and enhancement of decarboxylation of cysteine sulphinate and glutamate by the electrical stimulation of rat brain slices. Brain Research, 55, 173-178.

PASANTES-MORALES, H., KLETHI, J., LEDIG, M. and MANDEL, P. (1973a). Influence of light and dark in the free amino acid pattern of the developing chick retina. Brain Research, 57, 59-65. 
PASANTES-MORALES, H., URBAN, P. F. KLETHI, J. and MANDEL, P. (1973b). Light stimulated release of ${ }^{35} \mathrm{~S}$-taurine from chicken retina. Brain Research, 51, 375-378.

PERRY, T. L., HANSEN, S., BERRY, K., MOK, C. and LESK, D. (1971). Free amino acids and related compounds in biopsies of human brain. Journal of Neurochemistry, $18,521-528$.

PERRY, T. L., HANSEN, S., SOKOL, S. and WADA, J. A. (1972). Amino acids in brain biopsies of epileptogenic foci. Clinical Research, 20, 949.

SCARAGLI, G. and PAVAN, F. (1972). Effect of aminoacid compounds injected into cerebrospinal fluid spaces on colonic temperature, arterial blood pressure and behavior of the rat. Neuropharmacology, 11, 45-56.

SIEGHART, W. and KAROBATH, M.
(1974). Evidence for specific synaptosomal localization of exogenous accumulated taurine. Journal of Neurochemistry, 23, 911-915.

SUGIHARA, H., NAGASAWA, S. and OKABE, H. (1936). Experimentelle und klinische untersuchungen über taurin. Klinische Wochenschrift, 15, 751-756.

THURSBY, M. H. and NEVIS, A. H. (1974). Anticonvulsant activity of taurine in electrically and osmotically induced seizures in mice and rats. Federation Proceedings, 33, 1494.

TSUKADA, Y., INOUE, N., DONALDSON, J. and BARBEAU, A. (1974). Suppressive effects of various aminoacids against ouabain-induced seizures in rats. Canadian Journal of Neurological Sciences, 1, 214-221.

TURNER, F. P. and BLUM, V. C. (1964). The urinary excretion of free taurine in acute and chronic disease, following surgical trauma, and in patients with acute alcoholism. Journal of Surgical Research, 4, 423-431.

VAN GELDER, N. M. (1972). Antagonism by taurine of cobalt-induced epilepsy in cat and mouse. Brain Research, 47, 157,165.

VAN GELDER, N. M. and COURTOIS, A. (1972). Close correlation between changing content of specific amino acids in epileptogenic cortex of cats and severity of epilepsy. Brain Research, 43, 477-484.

VAN GELDER, N. M., SHERWIN, A. L. and RASMUSSEN, T. (1972). Amino acid content of epileptogenic human brain: focal versus surrounding regions. Brain Research, 40, 385-393.

WELTY, J. D. and READ, W. O. (1964). Studies on some cardiac effects of taurine. Journal of Pharmacology and Experimental Therapeutics, 144, 110-115. 